\title{
Whitening and Moisturizing Effects of Hydrolyzed Swiftlet Nest Extracts
}

\author{
Yun Jeong Kim ${ }^{1}$, Ye Sol Goh ${ }^{1}$, Waiting Cheung ${ }^{2}$, Yong Sam Kim ${ }^{3}$, Hyunsang Lee ${ }^{1 *}$ \\ ${ }^{1}$ Mannay Asia R\&D Center, Anyang-si, Gyeonggi-do, Korea \\ ${ }^{2}$ Shenzhen Mannay Cosmetic Co., Ltd, Shenzhen, Guangdong, China \\ ${ }^{3}$ Department of Cosmetic Engineering, Konkuk University, Seoul, Korea
}

\author{
*Corresponding author: Hyunsang Lee, \\ Mannay Asia R\&D Center, \#617, Heungandae- \\ ro 427 beon-gil 16, Dongan-gu, Anyang-si, \\ Gyeonggi-do 14059, Korea \\ Tel.: +827051335374 \\ Fax: +82 7082667879 \\ Email: andei.lee@mannay.com
}

Received September 09, 2021

Revised October 19, 2021

Accepted November 25, 2021

Published December 30, 2021

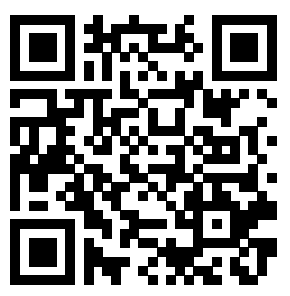

\begin{abstract}
Purpose: This research verified the skin whitening and moisturizing effects of hydrolyzed swiftlet nest extracts (HSNE) in vitro using human keratinocytes and melanoma. Methods: To confirm the antioxidant effect of HSNE, DPPH radicalscavenging activity was measured. To find out the whitening effect of HSNE, the genes related to melanogenesis, mRNA expression of tyrosinase $(T Y R)$, tyrosinase related protein (TRP) 1, 2 and microphthalmia associated transcription factor (MITF) were measured. We also measured the melanin contents after treatment of HSNE to confirm the anti-melanogenesis effect. Using reverse transcription polymerase chain reaction (RT-PCR), the genes related to moisturizing such as aquaporin ( $A Q P)$ 3 , hyaluronan synthase (HAS) 1,2 , and 3 were determined. The results of the tests were analyzed with student's t-test and expressed as mean \pm standard deviation. Results: DPPH radical scavenging effects of HSNE increased in a concentration dependent manner. The expression of melanogenesis-related genes were inhibited by the treatment of HSNE in a concentration-dependent manner (MITF, TYR, $T R P 1$, and 2). Melanin contents also decreased with the treatment of HSNE. The expression of moisturizing-related genes (HAS1, 2, 3, and $A Q P 3)$ increased in a concentration-dependent manner. Conclusion: It is confirmed that the hydrolyzed swiftlet nest extracts have skin whitening and moisturizing effects and can be used as a functional cosmetic raw material.
\end{abstract}

Keywords: Hydrolyzed swiftlet nest extracts, Moisturizing, Whitening, Anti-oxidant, Cosmetic raw material

\section{Introduction}

Swiftlet nest (Edible bird's nest) is made of the salivary secretion of specific swiftlets such as Aerodramus fuciphagus and Aerodramus maximus and most of edible bird's nest for consumption is harvested in the Southeast Asian region (Marcone, 2005). It has been used as a noble ingredient of an ancient Chinese delicacy. In particular, swiftlet nest soup has been consumed for a long time in Asia. Today, swiftlet nest is still a popular luxurious food supplement for women in the oriental area (Chan et al., 2013).

In the personal care industry, swiftlet nest extracts are used as an active raw material with International Nomenclature Cosmetic Ingredient (INCI) name of SWIFTLET NEST EXTRACTS.

The skin is an organ that surrounds the human body and protects the internal organs. Its functions are protection, regulation of body temperature, immune response, secretion, and regeneration. Among these functions, protection of the body from external stress and/or irritation, maintaining moisture, and supplying nutrients are most important (Kim \& Lee, 2008). In most organisms, the skin barrier, which is very close to skin protection, is located outside the body, implying that the stratum corneum exerts protective effects for the body by acting as a wall that inhibits water and nutrient loss and is a defense against 
bacteria, toxic materials, and/or UV radiation. Keratinocytes which are direct contact with environmental irritants, are under continuous stress from air pollutants and UV. Due to these irritants, cellular reactive oxygen species increase leading to a reduction in the moisturizing function of the skin, pigmentation, inflammation, and aging (Cross et al., 1987; Kim et al., 2012).

Melanocytes produce melanin pigment to protect skin cells from UV irradiation (Nordlund, 2007). However, UV irradiation induces inflammatory response, hormones, and stimulates melanocytes. Due to the overproduction of melanin, skin disorders such as freckles, solar lentigo, melasma, etc. (Nomakhosi \& Heidi, 2018; Pandya \& Guevara, 2000; Seo et al., 2018). The overproduction of melanin causes skin disorders, albeit Asians in particular like to maintain a light skin color due to white skin regarded as wealth and beauty (Hu et al., 2020). Therefore, anti-melanogenesis-related research has been increasing. The inhibition effects of melanogenesis-related genes such as microphthalmia-associated transcription factor (MITF), tyrosinase $(T Y R)$, tyrosinase related protein (TRP) 1, and TRP2 are widely used to verify the anti-melanogenesis effect of active compounds (Cha, 2018; Levy et al., 2006; Slominski et al., 2004).

Keratinocytes are the most abundant type of skin cell. Keratinocytes keep moisture via the production of intracellular lipids (Kim \& Kim, 2017). Hyaluronic acid is synthesized from hyaluronan synthase, which is a well-known moisturizing factor (Volpi et al., 2009), and aquaporin (AQP) 3 is also related to skin moisturizing. AQP3 is a water channel and aging related to skin dryness is a result of decreasing of AQP levels (Li et al., 2010; Shim, 2021).

In the present study, the effect of hydrolyzed swiftlet nest extracts (HSNE) on anti-melanogenesis and moisturizing were verified using skin cells in vitro to confirm the possibility of HSNE as a cosmetic raw material.

\section{Materials and Methods}

\section{Hydrolyzed swiftlet nest extracts (HSNE)}

HSNE was obtained from Shenzhen Mannay Cosmetic Co., Ltd (Shenzhen, China). The HSNE is prepared via enzyme treatment of swiftlet nest, which is gathered from the Southeast Asian area (Indonesia and Malaysia). The contents of $\mathrm{N}$-acetylneuraminic acid (NANA), an active compound of HSNE is about $10 \%$ of the weight of swiftlet nest extracts (Wong et al., 2018; Chan et al., 2018).

\section{Cell culture}

Human epidermal keratinocytes (HEKa) were purchased from Thermo Fisher Scientific (USA); human melanoma (SK-MEL2) cells were purchased from the Korea Type Culture Collection. HEKa was cultured in basal medium (Medium 154, Gibco, USA) supplemented with human keratinocyte growth supplement (HKGS; Gibco) and 100 units/mL of streptomycin (SigmaAldrich, USA). SK-MEL2 were cultured in Dulbecco's Modified Eagle's Medium (DMEM; Gibco) added with 10\% Fetal Bovine Serum (FBS; Gibco) and 100 units/mL of streptomycin (SigmaAldrich, USA). Cells were incubated at $37^{\circ} \mathrm{C}$ under $5 \% \mathrm{CO}_{2}$.

\section{Cell viability}

MTT (3-(4,5-dimethythiazol-2-yl)-2,5-diphenytetrazolium bromide, Sigma-Aldrich, USA) assay was carry out to assess the cytotoxicity. Cells were seed in 96-well-plates with 1.0 $\times 10^{5}$ cells/well and cultured for $24 \mathrm{~h}$ and cultured another $24 \mathrm{~h}$ after treatment of the samples. Cells were washed with phosphate buffered saline (10 mM, pH 7.4) and $150 \mu \mathrm{L}$ of MTT (final concentration $0.5 \mathrm{mg} / \mathrm{mL}$ ) was treated for $4 \mathrm{~h}$. Formed formazan was dissolved with $150 \mu \mathrm{L}$ of dimethyl sulfoxide (DMSO; Duchefa, Netherlands) for 15 min and we measured the absorbance at $570 \mathrm{~nm}$.

\section{DPPH free radical-scavenging activity assay}

The free radical-scavenging activity of HSNE were determined using 2,2-diphenyl-1-picrylhydrazyl (DPPH) assay. Briefly, $50 \mu \mathrm{L}$ of the diluted HSNE were mixed with $100 \mu \mathrm{L}$ of $0.1 \mathrm{mM}$ DPPH solution. DPPH solution without the test sample was used as a control. Next, the absorbance was measured at $515 \mathrm{~nm}$ after the mixture was incubated for $30 \mathrm{~min}$ at room temperature. The antioxidative activity was calculated using the formula below and expressed as the percentage of DPPH radical elimination.

[(Ablank-Asample)/Ablank] × 100 (\%)

Where Ablank is the absorbance of the blank DPPH solution and Asmaple is the absorbance of the DPPH solution after the addition of HSNE.

\section{Cellular melanin contents}

Two hundred $\mathrm{nM}$ of $\alpha$-melanocyte stimulating hormone ( $\alpha$-MSH; Sigma-Aldrich, USA) and test samples were treated in 
cultured SK-MEL2 and cultured for $48 \mathrm{~h}$ at $37^{\circ} \mathrm{C}$ under $5 \% \mathrm{CO}_{2}$. Cells were harvested using trypsin-EDTA and centrifuged at $12000 \mathrm{rpm}$ for $10 \mathrm{~min}$. One molar $\mathrm{NaOH}$ was added to dissolve melanin on cell pellets.

\section{Reverse transcription (RT)-PCR}

Isolated RNA was converted into cDNA using the PrimeScript 1st strand cDNA Synthesis Kit (TransGen, China). The converted cDNA was used as a template for amplification using PCR primers (Bioneer, Korea). The specific forward and reverse primers for each gene are presented in Table 1. Subsequently, the PCR products were loaded on a $1 \%$ agarose gel and evaluated using image analyzer (BioRad, USA).

\section{Results}

\section{Antioxidant effect of HSNE}

A DPPH assay was used to confirm the effect of HSNE on free radical scavenging. The results showed that the anti-oxidant effects of HSNE increased in a dose-dependent manner (Figure 1).

\section{Cytotoxicity}

The effect of HSNE on cell viability was evaluated after treatment for $24 \mathrm{~h}$ with HSNE at concentrations of 0, 100, 500, 1000, 2000, and $5000 \mu \mathrm{g} / \mathrm{mL}$. As shown in Figure 2, the cell viability of HEKa and SK-MEL2 cells were slightly decreased but in up to $5000 \mu \mathrm{g} / \mathrm{mL}$ of extracts, the viability of both cells were measured about $83 \%$ and $85 \%$ respectively; hence, it was considered non-cytotoxic (Figure 2).



Figure 1. Effects of HSNE on DPPH free radical-scavenging activity.

DPPH free radical-scavenging activity of HSNE was examined. Quercetin $(1000 \mu \mathrm{g} / \mathrm{mL})$ was used as a positive control (PC). The results are expressed as the mean $\pm S D$ of three independent experiments. *Statistically significant $(p<0.05)$. HSNE, hydrolyzed swiftlet nest extracts; DPPH, 2,2-diphenyl-1-picrylhydrazyl.

\section{Effects of HSNE on melanin synthesis in SK-MEL2 cells.}

The melanin contents of SK-MEL2 cells were verified after treatment with HSNE to assess the skin-whitening effects of HSNE. The results showed that $\alpha-\mathrm{MSH}$ induced melanin contents were increased while the melanin contents of the cells after treatment of HSNE were reduced: $158.83 \mu \mathrm{g} / \mathrm{mL}$ with $100 \mu \mathrm{g} / \mathrm{mL}$ extracts, $129.93 \mu \mathrm{g} / \mathrm{mL}$ with $200 \mu \mathrm{g} / \mathrm{mL}$ extracts, $115.47 \mu \mathrm{g} / \mathrm{mL}$ with $500 \mu \mathrm{g} / \mathrm{mL}$ extracts, and $103.15 \mu \mathrm{g} / \mathrm{mL}$ with $1000 \mu \mathrm{g} / \mathrm{mL}$ extracts compared to $\alpha-\mathrm{MSH}$ treated cells, whereas positive control, 4-n-butylresorcinol, resulted in melanin synthesis level of $95.57 \mu \mathrm{g} / \mathrm{mL}$ (Figure 3).

Table 1. Primer sequence

\begin{tabular}{lll}
\hline Primer & \multicolumn{1}{c}{ Forward sequence } & \multicolumn{1}{c}{ Reverse Sequence } \\
GAPDH ${ }^{* 1}$ & TCA GAA GGA CTC CTA TGT GG & TCT CTT TGA TGT CAG CAC G \\
GAPDH ${ }^{* 2}$ & CTG GCA CCC AGC ACA ATG AAG & ACC GAC TGC TGT CAC CTT CA \\
TRP1 & CTT TCT CCC TTC CTT ACT GG & TGG CTT CAT TCT TGG TGC TT \\
TRP2 & TGA GAA GAA ACA AAG TAG GCA CAA & CAA CCC CAA GAG CAA GAC GAA AGC \\
TYR & CAT TTT TGA TTT GAG TGT TCT & TGT GGT AGT CGT CTT TGT CC \\
MITF & TCG GAT CAT CAA GCA AGA AC & CCG AGG TTG TTG GTA AAG GT \\
HAS1 & GAC TCC TGG GTC AGC TTC CTA AG & GTA GAA CAG ACG CAG CAC AG \\
HAS2 & GCT ACC AGT TTA TCC AAA CG & GTG ACT CAT CTG TCT CAC CG \\
HAS3 & GGA AAG CTT GGC ATG TAC CGC AAC AG & AGA GGA GGG AGT AGA GGG AC \\
AQP3 & TGC AAT CTG GCA CTT CGC & GCC AGC ACA CAC ACG ATA A \\
\hline
\end{tabular}

${ }^{{ }^{1}}$ for SK-MEL2; ${ }^{* 2}$ for HEKa; GAPDH, glyceraldehyde-3-phosphate dehydrogenase; TRP, tyrosinase related protein; MITF, microphthalmia-associated transcription factor; $H A S$, hyaluronic acid synthase; $A Q P$, aquaporin 
A

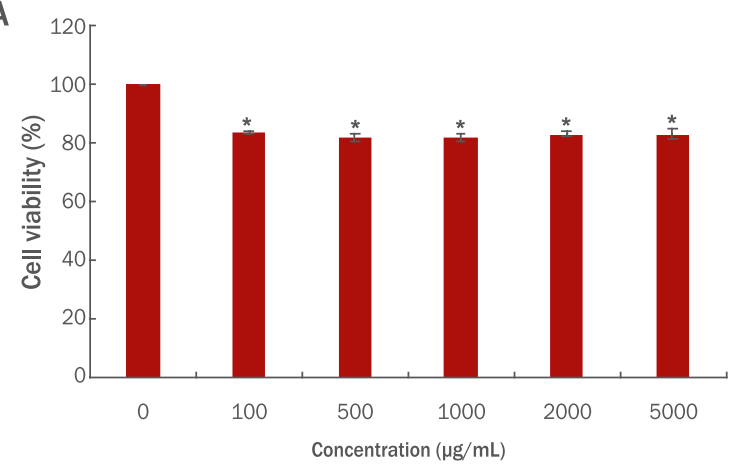

B

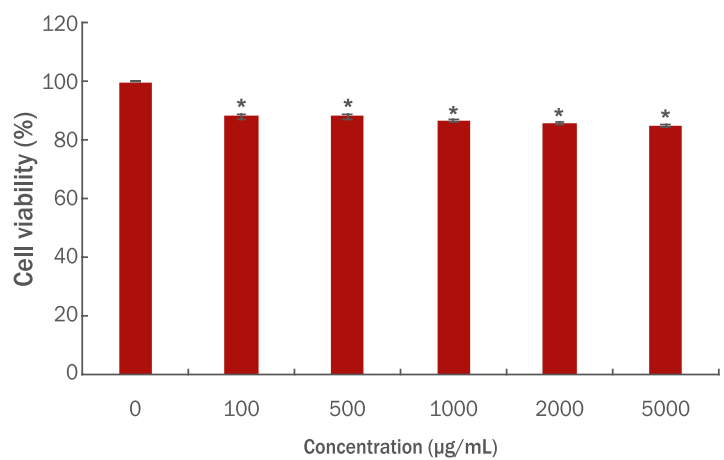

Figure 2. Cell viability of HSNE treated cells.

Cells were treated with HSNE at concentrations of $100,500,1000,2000$, and $5000 \mu \mathrm{g} / \mathrm{mL}$ for $24 \mathrm{~h}$. Cytotoxicity was measured using the MTT assay. The results are expressed as the mean \pm SD of three independent experiments. A, HEKa cells; B, SK-MEL2 cells. *Statistically significant $(p<0.05)$. HSNE, hydrolyzed swiftlet nest extracts; HEKa, human epidermal keratinocytes; SK-MEL2, human melanoma.

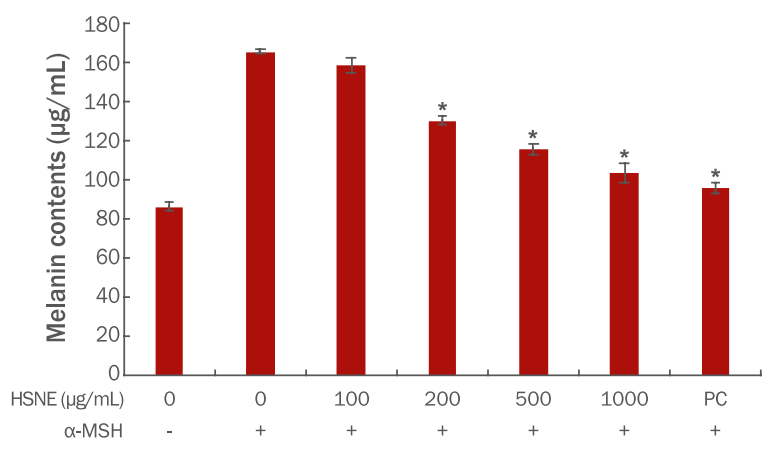

Figure 3. Melanin production of HSNE treated SK-MEL2 cell.

Cells were treated with HSNE at concentrations of 100, 200, 500 , and $1000 \mu \mathrm{g} / \mathrm{mL}$. 4-n-butylresorcinol $(20 \mu \mathrm{M})$ was used as a positive control (PC). The results are expressed as the mean $\pm S D$ of three independent experiments. *Statistically significant $(p<0.05)$. HSNE, hydrolyzed swiftlet nest extracts; SKMEL2, human melanoma.

\section{Effects of HSNE on gene expression levels of melanogenesis- related genes (TYR, TRP1, TRP2, and MITF)}

The effects of HSNE on TYR mRNA expression were studied using RT-PCR. We found that the expression of TYR mRNA in SK-MEL2 cells was inhibited in a concentration-dependent manner. TYR mRNA expression levels in $\alpha-\mathrm{MSH}$ treated cells were measured at $100.22 \%$ with $100 \mu \mathrm{g} / \mathrm{mL}$ extracts, $99.08 \%$ with $200 \mu \mathrm{g} / \mathrm{mL}$ extracts, $38.52 \%$ with $500 \mu \mathrm{g} / \mathrm{mL}$ extracts, and $37.12 \%$ with $1000 \mu \mathrm{g} / \mathrm{mL}$ extracts compared to $\alpha-\mathrm{MSH}$ treated cells, whereas $4-n$-butylresorcinol resulted in a TYR mRNA expression level of $40.69 \%$ (Figure $4 \mathrm{~A}$ ).

Similarly, the expression of TRP1 mRNA in SK-MEL2 cells was inhibited in a dose-dependent manner. TRP1 mRNA expression levels in $\alpha-\mathrm{MSH}$ treated cells were measured at $99.15 \%$ with $100 \mu \mathrm{g} / \mathrm{mL}$ extracts, $81.38 \%$ with $200 \mu \mathrm{g} / \mathrm{mL}$ extracts, $81.12 \%$ with $500 \mu \mathrm{g} / \mathrm{mL}$ extracts, and $63.88 \%$ with $1000 \mu \mathrm{g} / \mathrm{mL}$ extracts compared to $\alpha-\mathrm{MSH}$ treated cells, whereas 4-n-butylresorcinol resulted in a TRP1 mRNA expression level of $38.43 \%$ (Figure 4B).

HSNE inhibited the expression of TRP2 mRNA in SK-MEL2 cells. TRP2 mRNA expression levels in $\alpha-\mathrm{MSH}$ treated cells were measured at $99.59 \%$ with $100 \mu \mathrm{g} / \mathrm{mL}$ extracts, $97.74 \%$ with $200 \mathrm{ug} / \mathrm{mL}$ extracts, $85.68 \%$ with $500 \mathrm{ug} / \mathrm{mL}$ extracts, and $88.30 \%$ with $1000 \mathrm{ug} / \mathrm{mL}$ extracts compared to $\alpha-\mathrm{MSH}$ treated cells, whereas $4-\mathrm{n}$-butylresorcinol resulted in a TRP2 mRNA expression level of $51.21 \%$ (Figure $4 \mathrm{C}$ ).

MITF mRNA expression was similarly inhibited by HSNE in SK-MEL2 cells. MITF mRNA expression levels in $\alpha-\mathrm{MSH}$ treated cells were measured at $90.14 \%$ with $100 \mu \mathrm{g} / \mathrm{mL}$ extracts, $79.81 \%$ with $200 \mu \mathrm{g} / \mathrm{mL}$ extracts, $58.29 \%$ with $500 \mu \mathrm{g} / \mathrm{mL}$ extracts, and $62.50 \%$ with $1000 \mu \mathrm{g} / \mathrm{mL}$ extracts compared to $\alpha-\mathrm{MSH}$ treated cells, whereas $4-\mathrm{n}$-butylresorcinol resulted in a MITF mRNA expression level of $86.04 \%$ (Figure 4D).

\section{Effect of HSNE on moisturizing related gene expression (HAS1, HAS2, HAS3, and AQP3)}

RT-PCR was used to study the effects of HSNE on HAS1 mRNA expression were studied using RT-PCR. We found that the expression of HAS1 mRNA in HEKa cells was activated in a concentration-dependent manner. HAS1 mRNA expression levels were measured at $110.86 \%$ with $100 \mu \mathrm{g} / \mathrm{mL}$ extracts, 
A

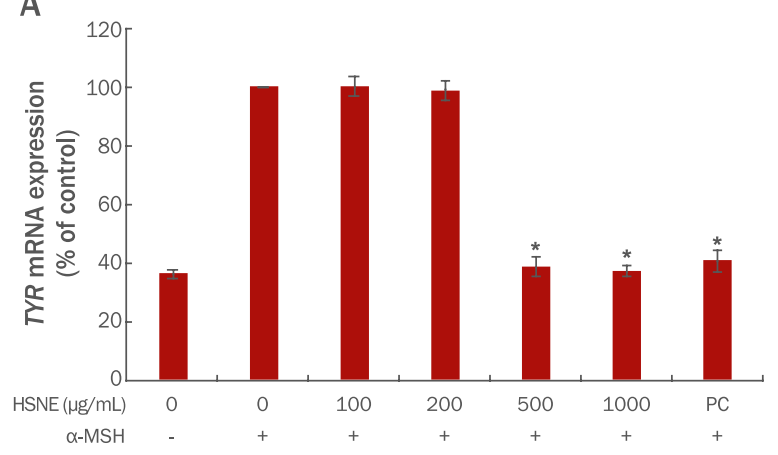

C

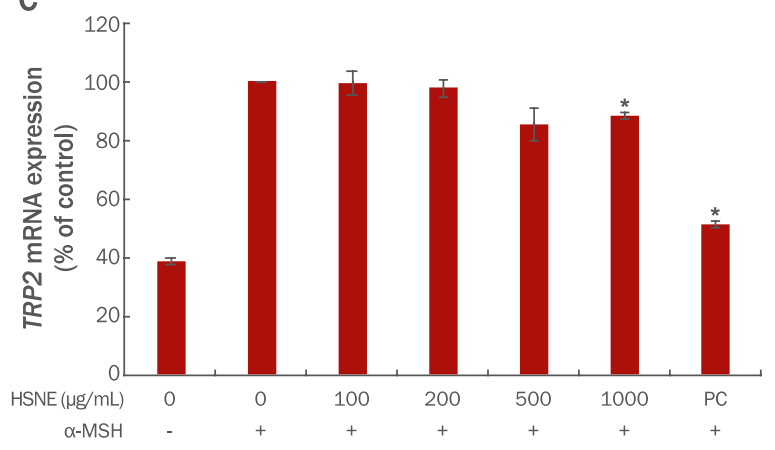

B



D

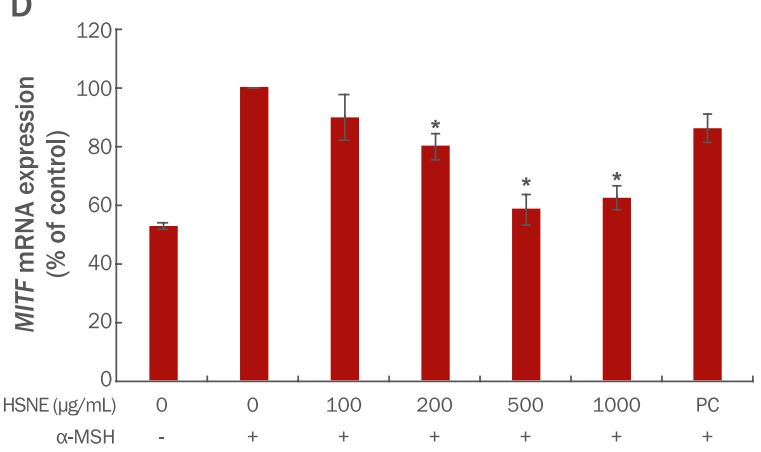

Figure 4. Effect of HSNE on melanogenesis-related mRNA expression.

Cells were treated with HSNE at concentrations of $100,200,500$, and $1000 \mu \mathrm{g} / \mathrm{mL}$. 4-n-butylresorcinol $(20 \mu \mathrm{M})$ was used as a positive control (PC). A, TYR; B, TRP1; C, TRP2; D, MITF. The results are expressed as the mean \pm SD of three independent experiments. ${ }^{*}$ Statistically significant $(p<0.05)$. HSNE, hydrolyzed swiftlet nest extracts; TYR, tyrosinase; TRP, tyrosinase related protein; MITF, microphthalmia-associated transcription factor.

$120.91 \%$ with $200 \mu \mathrm{g} / \mathrm{mL}$ extracts, $132.82 \%$ with $500 \mu \mathrm{g} / \mathrm{mL}$ extracts, and $142.46 \%$ with $1000 \mu \mathrm{g} / \mathrm{mL}$ extracts compared to normal state cells, whereas hyaluronic acid resulted in a HAS1 mRNA expression level of 152.26\% (Figure 5A).

Similarly, the expression of HAS2 mRNA increased in a dose-dependent manner. HAS2 mRNA expression levels were measured at $129.79 \%$ with $100 \mu \mathrm{g} / \mathrm{mL}$ extracts, $136.57 \%$ with $200 \mu \mathrm{g} / \mathrm{mL}$ extracts, $144.93 \%$ with $500 \mu \mathrm{g} / \mathrm{mL}$ extracts, and $153.35 \%$ with $1000 \mu \mathrm{g} / \mathrm{mL}$ extracts compared to normal state cells, whereas hyaluronic acid resulted in a HAS2 mRNA expression level of $163.52 \%$ (Figure 5B).

HSNE also affect the expression of HAS3 mRNA. HAS3 mRNA expression levels were measured as $121.74 \%$ with $100 \mu \mathrm{g} /$ $\mathrm{mL}$ extracts, $140.89 \%$ with $200 \mu \mathrm{g} / \mathrm{mL}$ extracts, $146.84 \%$ with $500 \mu \mathrm{g} / \mathrm{mL}$ extracts, and $162.75 \%$ with $1000 \mu \mathrm{g} / \mathrm{mL}$ extracts compared to normal state cells, whereas hyaluronic acid resulted in a HAS3 mRNA expression level of $158.62 \%$ (Figure 5C).

The expression of $A Q P 3$ mRNA was similarly improved by HSNE. The expression levels of $A Q P 3$ mRNA were measured at
$110.63 \%$ with $100 \mu \mathrm{g} / \mathrm{mL}$ extracts, $125.45 \%$ with $200 \mu \mathrm{g} / \mathrm{mL}$ extracts, $140.72 \%$ with $500 \mu \mathrm{g} / \mathrm{mL}$ extracts, and $158.11 \%$ with $1000 \mu \mathrm{g} / \mathrm{mL}$ extracts compared to normal state cells, whereas hyaluronic acid resulted in a AQP3 mRNA expression level of $150.82 \%$ (Figure 5D).

\section{Discussion}

Swiftlet nest has been used for a long time. From the beginning of the Tang dynasty, swiftlet nest has been an important item in Chinese cuisine and pharmacy (Marcone, 2005). In the present study, we evaluated the effect of hydrolyzed swiftlet nest extracts on skin whitening and moisturizing were measured.

HSNE showed antioxidant effect in a dose-dependent manner (Figure 1). Using rat models, Yida et al. (2015) reported that the swiftlet nest attenuates high fat diet-induced oxidative stress. Guo et al. (2016) showed that NANA administration decreased 

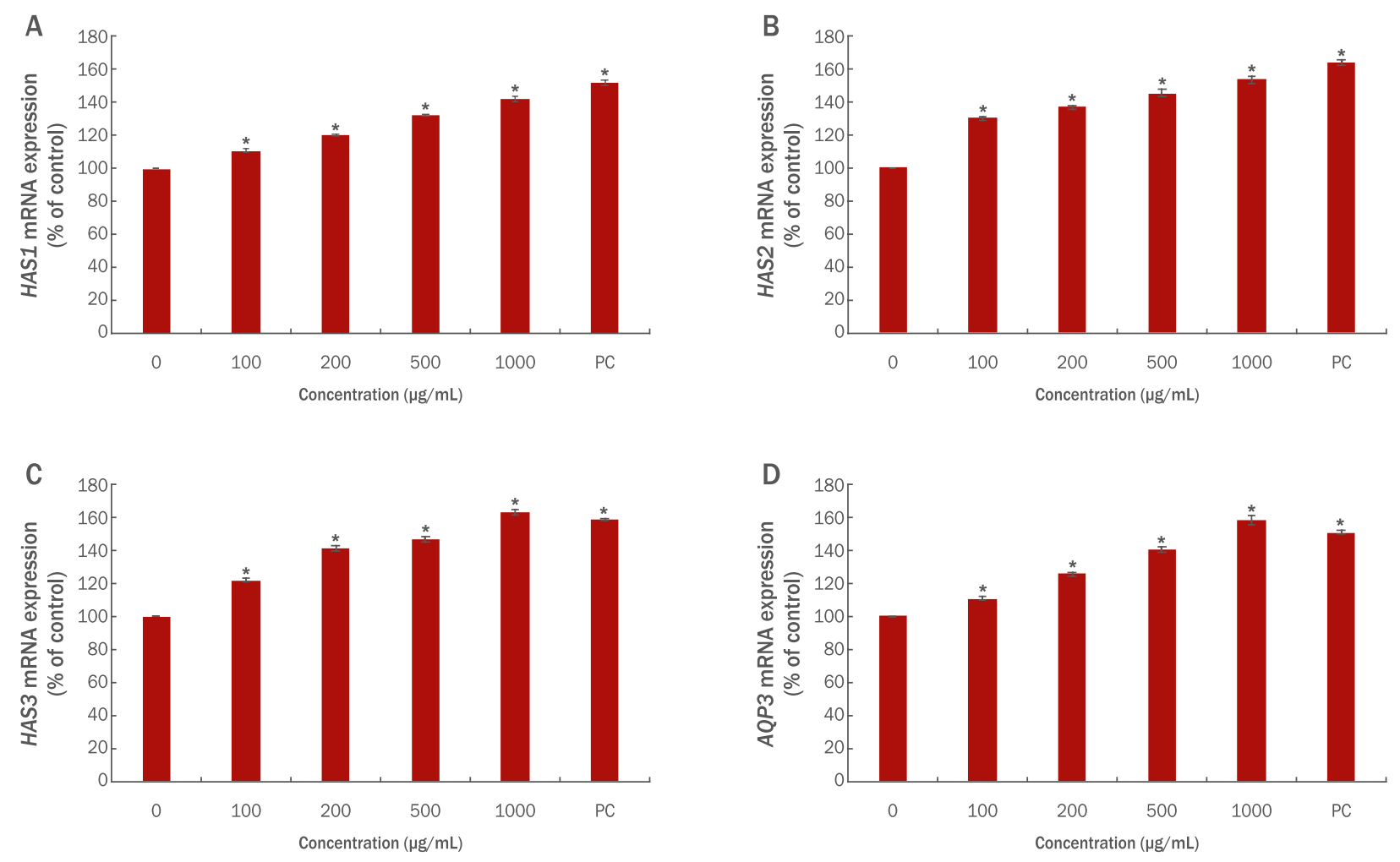

Figure 5. Effects of HSNE on HAS1, 2, 3, and AQP3 mRNA expression.

Cells were treated with HSNE at concentrations of 100, 200, 500, and $1000 \mu \mathrm{g} / \mathrm{mL}$. Hyaluronic acid (50 $\mu \mathrm{g} / \mathrm{mL})$ was used as a positive control (PC). A, HAS1; B, HAS2; C, HAS3; D, AQP3. The results are expressed as the mean \pm SD of three independent experiments. ${ }^{*}$ Statistically significant $(p<0.05)$. HSNE, hydrolyzed swiftlet nest extracts; $H A S$, hyaluronic acid synthase; $A Q P$, aquaporin.

oxidative stress by increasing antioxidant enzymatic activity and protein expression of paraoxonase 1 and 2 . Hydrolyzation of the swiftlet nest extracts maximizes the NANA contents compared to those of non-hydrolyzed extracts (Wong et al., 2018).

Using melanogenesis-related genes such as MITF, TYR, TRP1, and TRP2, HSNE was shown to exert anti-melanogenesis effects in human melanoma cells.

MITF is a transcriptional regulation factor and triggers major proteins for the synthesis of melanin; Tyrosinase, TRP1, and TRP2, and these proteins synthesize melanin in melanosome from tyrosine through DOPA, DOPA chrome, and DOPA quinone. MITF mRNA expression was inhibited with the treatment of HSNE, $62.50 \%$ of MITF mRNA was expressed with the treatment of $1000 \mu \mathrm{g} / \mathrm{mL}$ HSNE compared to those treated with $\alpha-\mathrm{MSH}$ only (Figure 4D).

The mRNA expressions of TYR, TRP1, and TRP2 were also decreased with the treatment of HSNE in melanoma. At the concentration of $1000 \mu \mathrm{g} / \mathrm{mL}$ of HSNE, the TYR, TRP1, and
TRP2 mRNA expressions were measured at 37.12\%, 63.88\%, and $88.30 \%$ compared to those treated with $\alpha-\mathrm{MSH}$ only, respectively (Figure $4 \mathrm{~A}, \mathrm{~B}$, and C).

TRP1 is known for its dihydroxyindole carboxylic acid oxidase activity. It is also involved in stabilizing tyrosinase (Sarangarajan \& Boissy, 2001) TRP2, DOPAchrome tautomerase, catalyzes the conversion of DOPAchrome to 5,6, dihydroxyindole-2-carboxylic acid. HSNE inhibited $\alpha-\mathrm{MSH}$ induced melanogenesis with downregulation of melanogenesis-related gene expression such as that of TYR, TRP1, and TRP2.

HSNE showed anti-melanogenesis effects in the inhibition of melanogenesis related mRNA expression also confirming that HSNE inhibits melanin production. As shown in Figure 3, melanin production was inhibited with HSNE in a concentrationdependent manner. SK-MEL2 cells treated with $1000 \mu \mathrm{g} /$ mL HSNE produced $103.15 \mu \mathrm{g} / \mathrm{mL}$ melanin, which was approximately reduced to about 38\% lower levels of $\alpha-\mathrm{MSH}$ treatment only. 
Sialic acid is a main active compound found in swiftlet nest and NANA is a major sialic acid structure detected in swiftlet nest that can be obtained from the hydrolysis of swiftlet nest (Chan et al., 2013; Marcone, 2005; Pozsgay et al., 1987; Van der Ham et al., 2007). In swiftlet nest, there are two forms of NANA: loosely attached on the surface of swiftlet nest (free NANA) and/or covalently bound to glycan molecules and linked to protein mass (conjugated NANA). With hydrolyzation steps in the manufacturing process of the swiftlet nest extracts, the free NANA contents in the extracts are maximized (Wong et al., 2018)

Previous studies found that the digestion of swiftlet nest with simulated gastric fluid fully released NANA in a free form and the digested swiftlet nest extracts showed strong inhibition of tyrosinase activity (Chan et al., 2015; Chan et al., 2018; Wong et al., 2018).

Moisturizing is the most essential function of cosmetics and is related to maintenance of the skin barrier and a healthy skin. Hyaluronic acid synthase (HAS) is a well-known enzyme that synthesizes hyaluronic acid in mammals (Itano \& Kimata, 1996; Kim et al., 2004). Volpi et al. (2009) reported that HAS1 produces small amounts of high molecular weight hyaluronic acid, HAS2 produces significantly higher molecular weight hyaluronic acid and HAS3 is the most active of the hyaluronic acid synthases, yet produces low molecular weight hyaluronan chains. AQP water channels regulate transcellular water flow (Day et al., 2014). In particular, AQP3 is abundantly expressed in the basal epidermal cell layer in mammals (Sougrat et al., 2002) responsible for water and glycerol transport throughout the stratum corneum layer and is required for the maintenance of skin moisture (Volpi et al., 2009).

In the present study, RT-PCR was used to evaluate the moisturizing effects of HSNE. HSNE showed upregulation of HAS1, HAS2, HAS3, and AQP3 in a dose-dependent manner as shown in Figure 5. With treatment of $1000 \mu \mathrm{g} / \mathrm{mL}$ HSNE, HAS1, $H A S 2, H A S 3$, and AQP3 mRNA expression were measured at $142.46,153.35,162.75$, and $158.11 \%$ compared with a normal cell, respectively. Lai et al. (2021) reported the digested (hydrolyzed) swiftlet nest extracts showed moisturizing effect in vitro and ex vivo models and the effects were better than that of non-hydrolyzed extracts due to sialic acid and water-soluble molecules by promoting the filaggrin gene expression.

From these results, it is confirmed that moisturizing related genes, HAS1, HAS2, HAS3, and AQP3 mRNA expression are increased with HSNE treatment.

\section{Conclusion}

HSNE is effective in skin whitening with inhibition of melanogenesis related gene expression such as MITF, TYR, TRP1, and TRP2. Moreover, it has a moisturizing effect with an upregulation of moisturizing related genes (HAS1, HAS2, HAS3, and $A Q P 3)$. HSNE can be used as a functional cosmetic raw material focused on whitening and moisturizing.

\section{Acknowledgements}

This study was supported by Shenzhen Mannay Cosmetic Co., Ltd (Shenzhen, China).

\section{Author's contribution}

YJK, YSK, and HL designed the study and drafted the manuscript. YJK, YSG, and HL carried out the biochemical assays and revised the manuscript. WC and YSG performed the statistical analysis and helped to revise the manuscript. YJK and HL participated in its design and coordination and helped to draft the manuscript. All authors read and approved the final manuscript.

\section{Author details}

Yun Jeong Kim (Principal Researcher), Mannay Asia R\&D Center, Heungandae-ro 427beon-gil 16, Dongangu, Anyang-si, Gyeonggi-do 14059, Korea; Ye Sol Goh(Researcher), Mannay Asia R\&D Center, Heungandaero 427beon-gil 16, Dongan-gu, Anyang-si, Gyeonggido 14059, Korea; Waiting Cheung (Chief Executive Officer) Room 2008, \#A, Jiahe Huaqiang Building, Shennan Middle Road, Futian District, Shenzhen, Guangdong 518000, China; Yong Sam Kim (Professor), Department of Cosmetic Engineering, Konkuk University, 120 Neungdong-ro, Gwangjin-gu, Seoul 05029, Korea; Hyunsang Lee (R\&D Director), Mannay Asia R\&D Center, Heungandae-ro 427beon-gil 16, Dongan-gu, Anyang-si, Gyeonggi-do 14059, Korea

\section{References}

Cha HJ. Cnidium officinale Makino extracts inhibit $\alpha-\mathrm{MSH}-$ induced melanogenesis in B16F10 mouse melanoma cells. Asian Journal of Beauty and Cosmetology, 16:122- 
130, 2018.

Chan GKL, Zheng YZ, Zhu KY, Dong TTX, Tsim KW. Determination of free $\mathrm{N}$-acetylneuraminic acid in edible bird nest: a development of chemical marker for quality control. The Journal of Ethnobiology and Traditional Medicine. 120: 620-628, 2013.

Chan GKL, Wong ZCF, Lam KYC, Cheng LKW, Zhang LM, Lin H, Dong T, Tsim KWK. Edible bird's nest, an Asian health food supplement, possesses skin lightening activities: identification of $\mathrm{N}$-acetylneuraminic acid as active ingredient. Journal of Cosmetics, Dermatological Sciences and Applications, 5: 262-274, 2015.

Chan GKL, Wu KQY, Fung AHY, Poon KKM, Wang CY, Gridneva E, Huang RRH, Fung SYZ, Xia YT, Hu WWH, Wong ZCF, Tsim KWK. Searching for active ingredients in edible bird's nest. Journal of Compliment Medicine and Alternative Healthcare, 6: 555683, 2018.

Cross CE, Halliwell B, Borish ET, Pryor WA, Ames BN, Saul RL, McCord JM, Harman D. Oxygen radicals and human disease. Annals of Internal Medicine, 107: 526-545, 1987.

Day RE, Kitchen P, Owen DS, Bland C, Marshall L, Conner AC, Bill RM, Conner MT. Human aquaporins: regulators of transcellular water flow. Biochimica et Biophysica Acta, 1840: 1492-1506, 2014.

Guo S, Tian H, Dong R, Yang N, Zhang Y, Yao S, Li Y, Zhou Y, Si Y, Qin S. Exogenous supplement of N-acetylneuraminic acid ameliorates atherosclerosis in apolipoprotein E-deficient mice. Atherosclerosis, 251: 183-191, 2016.

Hu Y, Zeng H, Huang J, Jiang L, Chen J, Zeng Q. Traditional Asian herbs in skin whitening: the current development and limitations. Frontiers in Pharmacology, 11: 982, 2020.

Itano N, Kimata K. Molecular cloning of human hyaluronan synthase. Biochemical and Biophysical Research Communications, 222: 816-820, 1996.

Kim S, Kang BY, Cho SY, Sung DS, Chang HK, Yeom MH, Kim $\mathrm{DH}$, Sim YC, Lee YS. Compound $\mathrm{K}$ induces expression of hyaluronan synthase 2 gene in transformed human keratinocytes and increases hyaluronan in hairless mouse skin. Biochemical and Biophysical Research communication, 316: 348-355, 2004.

Kim HJ, Lee SH. The effect of skin surface on epidermal permeability barrier. The Journal of Skin Barrier Research, 10: 44-55, 2008.
Kim ES, Kim JS, Kim GN. Anti-oxidant function of genistein against $\mathrm{H} 2 \mathrm{O} 2$-induced oxidative stress in $\mathrm{HaCaT}$ keratinocytes. Asian Journal of Beauty and Cosmetology, 10: 541-547, 2012.

Kim B, Kim HS. Antimicrobial activities and skin barrier improvement effect of Eruca sativa extracts. Korean Journal of Food Preservation, 24: 320-324, 2017.

Lai QWS, Guo MSS, Wu KQ, Liao Z, Guan D, Dong TT, Tong P, Tsim KWK. Edible bird's nest, an Asian Health food supplement, processes moisturizing effect by regulating expression of filaggrin in skin keratinocyte. Frontiers in Pharmacology, 12: 685982, 2021.

Levy C, Khaled M, Fisher DE. MITF: master regulator of melanocyte development and melanoma oncogene. Trends in Molecular Medicine, 12: 406-414, 2006.

Li J, Tang H, Hu X, Chen M, Xie H. Aquaporin-3 gene and protein expression in sun-protected human skin decreases with skin ageing. The Australiasian Journal of Dermatology, 51: 106-102, 2010.

Marcone, Massimo F. Characterization of the edible bird's nest the "Caviar of the East". Food Research International, 38: 1125-1134, 2005.

Nomakhosi M, Heidi A. Natural options for management of melasma, a review. Journal of Cosmetic and Laser Therapy, 20: 470-481, 2018.

Nordlund JJ. The melanocyte and the epidermal melanin unit: an expanded concept. Dermatologic Clinics, 25: 271-281, 2007.

Pandya AG, Guevara IL. Disorders of hyperpigmentation. Dermatologic Clinics. 18: 91-98, 2000.

Pozsgay V, Jennings H, Kasper DL. 4,8-Anhydro-Nacetylneuraminic acid Isolation from edible bird's nest and structure determination. European Journal of Biochemistry, 162: 445-450, 1987.

Sarangarajan R, Boissy RE. Tyrp1 and oculocutaneous albinism type 3. Pigment Cell Research, 14: 437-444, 2001.

Seo SK, Han SJ, Ku CS, Kim DH, Ryu JH, Baek JH, Koh JS, Jang DI. New development of natural depigmentation agent from Anemarrhena asphodeloides root extracts by inhibition of melanin biosynthesis. Asian Journal of Beauty and Cosmetology, 16: 1-9, 2018.

Shim JH, Anti-aging Effect of ganoderol A in UVA-irradiated normal human epidermal keratinocytes. Asian Journal of 
Beauty and Cosmetology, 19: 57-64, 2021.

Slominski A, Tobin DJ, Shibahara S, Wortsman J. Melanin pigmentation in mammalian skin and its hormonal regulation. Physiological Research, 84: 1155-1228, 2004.

Sougrat R, Mornd M, Gondran C, Barre P, Gobin R. Bonte F. Dumas M, Verbavatz JM. Functional expression of AQP3 in human skin epiermis and reconstructed epidermis. The Journal of Investigative Dermatology, 118: 678-685, 2002.

Van der Ham M, Prinsen BHCMT, Huijmans JGM, Abeling NGGM, Dornald B, Berger R, De Koning TJ, De Sain-van der Velden MGM. Quantification of free and total sialic acid excretion by LC-MS/MS. Journal of Chromatography $B$, 848: 251-257, 2007.
Volpi N, Schiller J, Stern R, Šoltés L. Role, metabolism, chemical modifications and applications of hyaluronan. Current Medicinal Chemistry, 16: 1718-1745, 2009.

Wong ZCF, Chan GKL, Wu KQY, Poon, KKM, Chen Y, Dong TTX, Tsim KWK. Complete digestion of edible bird's nest releases free $\mathrm{N}$-acetylneuraminic acid and small peptides: an efficient method to improve functional properties. Food \& Function, 9: 5139-5149, 2018.

Yida Z, Imam MU, Ismail M, Hou Z, Abdullah MA, Ideris A, Ismail N. Edible Bird's Nest attenuates high fat dietinduced oxidative stress and inflammation via regulation of hepatic antioxidant and inflammatory genes. $B M C$ Complementary and Alternative Medicine, 15: 310, 2015. 


\section{국문초록}

\section{하이드롤라이즈드금사연둥지추출물의 미백 및 보습 효과}

김윤정 ${ }^{1}$, 고예솔 ${ }^{1}$, 청와이팅 $^{2}$, 김영삼 ${ }^{3}$, 이현상 $^{1 *}$

${ }^{1}$ 매니아시아알엔디센터, 경기도 안양시, 한국

${ }^{2}$ 선전매니화장품, 선전, 중국

${ }^{3}$ 건국대학교 화장품공학과, 서울, 한국

목적: 본 연구는 hydrolyzed swiftlet nest extracts (HSNE)의 피부 미백 및 보습 효과를 확인하고자 한다. 방법: HSNE의 항산화 효 과를 확인하기 위해 DPPH 라디칼 소거 활성 평가 및 미백 관련 유전자인 tyrosinase (TYR), tyrosinase related protein (TRP) 1, TRP2 및 MITF의 발현을 확인하였다. 또한 melanin 생합성 저해 활성을 확인하여 HSNE의 미백 효과를 확인하였다. 보습 효과를 확인하기 위하여 관련 유전자인 hyaluronan synthase (HAS) 1,2,3 및 aquaporin (AQP) 3의 발현을 revers transcription-PCR을 통해 확인하였다. 실험 결과는 평균치와 표준편차로 나타내었고, 결과는 $t$-test를 사용하여 분석하였다. 결과: $\mathrm{HSNE}$ 는 $\mathrm{DPPH}$ 라 디칼 소거 활성을 증가시켜 항산화 작용을 보였다. 또한 TYR, TRP1, TRP2 및 MITF의 발현을 감소시키고 melanin 생합성을 억제 함으로써 미백효과를 지니는 것을 확인하였다. $H A S 1,2,3$ 및 $A Q P 3$ 의 발현을 증가시켜 피부 보습 효과를 지니는 것을 확인하였다. 결론: Hydrolyzed swiftlet nest extracts는 피부 미백 및 보습 효과를 갖는 기능성 화장품 원료로 적용 가능하다.

핵심어: 하이드롤라이즈드금사연둥지추출물, 보습, 미백, 항산화, 화장품원료

This study was supported by Shenzhen Mannay Cosmetic Co., Ltd (Shenzhen, China).

\section{참고문헌}

김현정, 이승헌. 피부 표면 $\mathrm{pH}$ 가 피부 장벽 기능에 미치는 영향. 한국피부장벽학회지, $10: 44-55,2008$.

김의수, 김종식, 김교남. $\mathrm{H}_{2} \mathrm{O}_{2}$ 로 산화적 스트레스가 유도된 $\mathrm{HaCaT}$ Ketatinocytes에서 Genistein의 항산화활성. 아시안 뷰티화장품학술지, 10: $541-547,2012$.

루꼴라(Eruca sativa) 추출물의 항균활성과 피부장벽 개선 효과. 한국식품저장유통학회지, 24: 320-324, 2017.

서수경, 한성정, 구창섭, 김대현, 류자현, 백지훈, 고재숙, 장동일. 아시안뷰티화장품학술지, 16:1-9, 2018.

심중현. 자외선 조사에 의해 노화된 인간각질형성세포에서 Ganoderol A의 항노화 효능. 아시안뷰티화장품학술지, 19: 57-64, 2021.

차화준. B16F10 mouse melanoma 세포에서 Cnidium officinale Makino 추출물의 $\alpha$-MSH에 의해 유도된 melanogenesis 억제효과. 아시안뷰티화장품학술지, 16: 122-130, 2018. 


\section{中文摘要}

\section{水解小雨燕窝提取物的美白保湿作用}

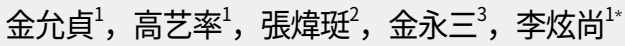

绵俪亚洲研发中心，京畿道安养市，韩国

2深圳绵俪日用化工有限公司，深圳，中国

3建国大学化妆品工学科, 首尔, 韩国

目的: 本研究使用人角质形成细胞和黑色素瘤在体外验证水解小雨燕窝提取物（HSNE）的皮肤美白和保湿效 果。方法: 为了确认HSNE的抗氧化作用, 测量了DPPH 自由基清除活性。为了找出HSNE的美白效果, 测量了 与黑色素生成相关的基因、酪氨酸酶（TYR）、酪氨酸酶相关蛋白（TRP）1、2和MITF的 mRNA表达。并测 量了HSNE处理后的黑色素含量, 以确认抗黑色素生成作用。使用逆转录聚合酶链反应 (RT-PCR), 确定了与 保湿相关的基因，例如水通道蛋白 $(A Q P) 3$ 、透明质酸合成酶(HAS) 1、2 和3。测试结果用student's $t$-test分 析并表示为平均值士标准差。结果: HSNE的DPPH自由基清除作用以浓度依赖性方式增加。此外，通过降低 $T Y R 、 T R P 1 、 T R P 2$ 和MITF的表达，抑制黑色素生物合成，证实具有美白作用。保湿相关基因（HAS1、2、3 和 $A Q P 3$ ）的表达以浓度依赖性方式增加，证明其保湿效果。结论：经证实水解小雨燕窝提取物具有美白保湿作 用，可作为功能性化妆品原料。

关键词: 水解小雨燕窝，保湿，美白，抗氧化，化妆品原料 
